\title{
Формирование атомарно-гладкой эмитирующей поверхности полупрозрачного p-GaAs(Cs,O) - фотокатода
}

\author{
В.В. Бакин ${ }^{1)}$, С.А. Рожков ${ }^{1,2)}$, Г.Э. Шайблер ${ }^{1,2)}$, С.Н. Косолобов ${ }^{1)}$, Н.С. Рудая ${ }^{1)}$, А.С. Кожухов ${ }^{1,2)}$, \\ A.C. Терехов ${ }^{1)}$ \\ ${ }^{1}$ ИФП СО РАН, Новосибирск, 630090, пр. ак. Лаврентьева, 13 \\ ${ }^{2}$ НГУ, Новосибирск, 630090, ул. Пирогова, 2 \\ тел:(383) 330-98-74 эл. почma: bakin@ngs.ru
}

DOI 10.34077/RCSP2019-155

Полупрозрачные p-GaAs(Cs,O) - фотокатоды (ПФК) с эффективным отрицательным электронным сродством (ОЭС) широко используются в современных фотоприёмниках различного назначения и поэтому, поиск путей повышения их технических характеристик является актуальной научной задачей. В настоящее время принято считать, что основные характеристики $\mathrm{p}-\mathrm{GaAs}(\mathrm{Cs}, \mathrm{O})$ фотокатодов, такие как вероятность выхода фотоэлектронов в вакуум и угловое распределение эмитированных фотоэлектронов, ограничены шероховатостью эмитирующей поверхности p-GaAs слоя [1]. В данной работе впервые экспериментально показана возможность формирования атомарно - гладкой эмитирующей поверхности p-GaAs - слоя полупрозрачного фотокатода на подложке из «толстого» стекла без введения дислокационной сетки в полупроводниковую структуру. В экспериментах использовались многослойные гетероэпитаксиальные структуры (ГЭС), выращенные методом МОС - гидридной эпитаксии. В качестве просветляющего покрытия ГЭС был использован $\mathrm{SiO}$ - слой. Сочленение ГЭС со стеклянной подложкой выполнено электродиффузионной сваркой. Выбранные материалы и режимы сварки исключали введение дислокаций в ГЭС. Для удаления GaAs-подложки и «стопорного» AlGaAs - слоя использовались селективные травители на основе $\mathrm{NH}_{4} \mathrm{OH}: \mathrm{H}_{2} \mathrm{O}_{2}$ и $\mathrm{HCl}$, соответственно. Среднеквадратичная шероховатость поверхности активного $\mathrm{p}$ -

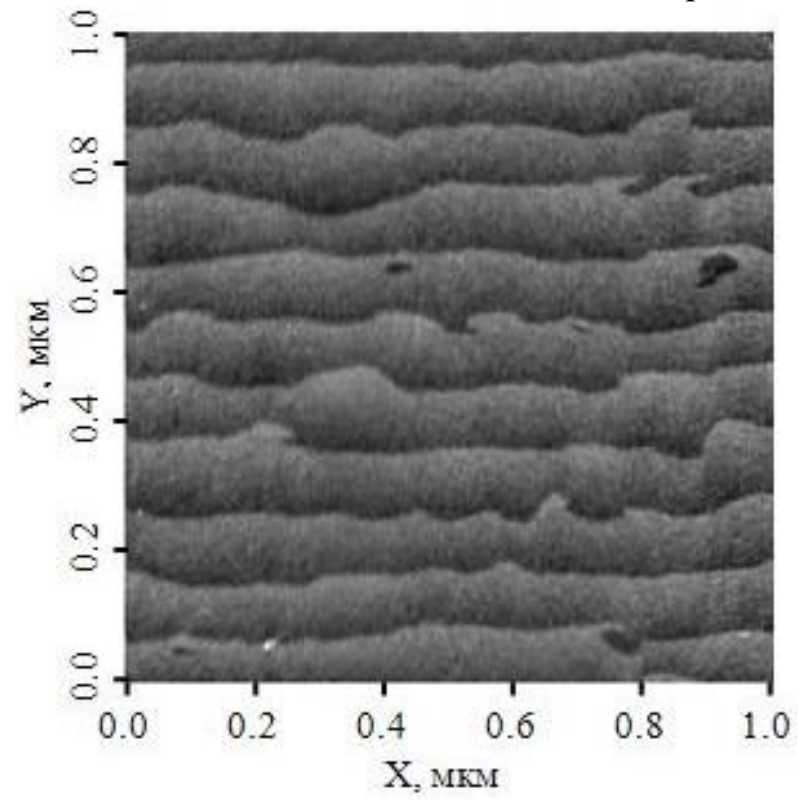

$\mathrm{GaAs}$ - слоя после использования селективных травителей, измеренная атомно - силовым микроскопом (АСМ), была близка к 0.2 нм. Финишное «выглаживание» эмитирующей поверхности p-GaAs - слоя включало два этапа. На первом этапе мы использовали химикомеханическое полирование (XМП) p-GaAs-слоя в разбавленном щелочном растворе оригинального состава без использования абразивных материалов. После ХМП среднеквадратичная шероховатость поверхности $\mathrm{p}-\mathrm{GaAs}$ - слоя не превышала $\sim 0.1 \mathrm{Hм}$. Дальнейшее «выглаживание» поверхности p-GaAs слоя ПФК проводилось путём его прогрева в «равновесных» условиях. Для обеспечения этих условий поверхность $\mathrm{p}-\mathrm{GaAs}$ - слоя ПФК «прикрывалась» $\mathrm{p}$-GaAs - слоем идентичного состава и помещалась в «самодельную» печь, заполненную чистым водородом. Прогрев проводился в равновесных условиях, в которых потоки мышьяка, галлия и цинка из p-GaAs - слоя ПФК и «прикрывающего» p-GaAs - слоя уравновешивали друг друга. Рельеф эмитирующей поверхности p-GaAs-слоя ПФК после второго этапа «выглаживания», измеренный методом АCM, показан на рисунке. Из рисунка следует, что на поверхности p-GaAs - слоя сформировались регулярные террасы атомной высоты. Появление атомарно - гладких террас на поверхности p-GaAs - слоя указывает на то, что снижение удельной свободной энергии поверхности обусловлено снижением её удельной энтальпии. Фотолюминесцентное изображение p-GaAs - слоя «показало» отсутствие следов дислокационной сетки в фотокатодной структуре. Мы полагаем, что дальнейшее совершенствование предложенной методики финишной обработки поверхности p-GaAs-слоя позволит создать ПФК с физически предельными характеристиками.

\section{Лuтература}

[1] S. Karkare, I. Bazarov //Appl. Phys. Lett. 2011. V.98. No 3.P. 094104(3). 